\title{
Small intestinal submucosal lipoma: a rare cause of secondary intussusception in a child
}

\author{
Taycir Cheikhrouhou ${ }^{1,2^{*}}$ (D), Mahdi Ben Dhaw ${ }^{1,2}$, Mohamed Zouari ${ }^{1,2}$, Hayet Zitouni ${ }^{1,2}$, Rim Kallel ${ }^{2,3}$, \\ Naourez Gouiaa ${ }^{2,3}$, Tahya Sellami Boudawara ${ }^{2,3}$ and Riadh Mhiri, ${ }^{1,2}$
}

\begin{abstract}
Background: Intestinal lipomas are benign, non-epithelial, intestinal tumors with an exceptionally rare localization at the ileum. Lipomas in the small intestine occur mainly in elderly patients and seldom occur in childhood. They are frequently asymptomatic, possibly due to their slow growth. These tumors may act as a lead point of intussusception.

Case presentation: We report a rare case of double compounded ileo-ileal intussusception due to a submucosal intestinal lipoma in an 8-year-old female. To our knowledge, this is only the seventh pediatric case to be reported in the medical literature.

Conclusions: Small intestinal submucosal lipoma should be considered in case of intussusception in pediatric patients. Surgical resection seems sufficient in case of symptomatic intestinal lipoma with low morbidity.
\end{abstract}

Keywords: Lipoma, Small bowel, Intussusception, Child, Case report

\section{Background}

Lipomas can develop in virtually all organs. They are benign soft tissue tumors derived from mature adipocytes. Lipomas of the gastrointestinal tract (GIT) are rare [1]. Most GIT lipomas are asymptomatic [2] and $<50 \%$ of adult patients who have intestinal lipomas become symptomatic, usually because of intussusception, obstruction, or hemorrhage [3]. Pediatric intestinal lipomas, although rare, have previously been reported as the leading point of intussusception [4].

We describe a pediatric case of intussusception secondary to a GIT lipoma and present a review of the literature on small bowel intussusception due to gastrointestinal lipomas.

\footnotetext{
* Correspondence: cheikhrouhoutaycir@gmail.com

${ }^{1}$ Department of Pediatric Surgery, Hedi Chaker Hospital, 3029 Sfax, Tunisia

${ }^{2}$ University of Medicine of Sfax, University of Sfax, Sfax, Tunisia

Full list of author information is available at the end of the article
}

\section{Case presentation}

An 8-year-old girl was admitted to our hospital with abdominal pain and vomiting that had started 2 days before admission. During questioning, the patient mentioned having an intermittent colicky pain in her right lower abdomen over the previous month that had not responded to analgesia or spasmolytic. There were no episodes of bilious vomiting, bloody stools, or fever.

On admission, the patient was hemodynamically stable with a blood pressure of $110 / 70 \mathrm{mmHg}$. Her temperature was $37.2{ }^{\circ} \mathrm{C}$. Clinical examination revealed tenderness at the right iliac fossa without abdominal distension or signs of peritoneal irritation. Rectal examination was normal. A complete blood cell count and laboratory tests were normal. Abdominal X-ray revealed no specific bowel gas pattern, but gaseous distension of several small bowel loops (Fig. 1).

Abdominal ultrasound revealed the typical target sign in the right lower abdomen suggestive of ileocolic intussusception, extending for approximately $9.6 \mathrm{~cm}$. In 


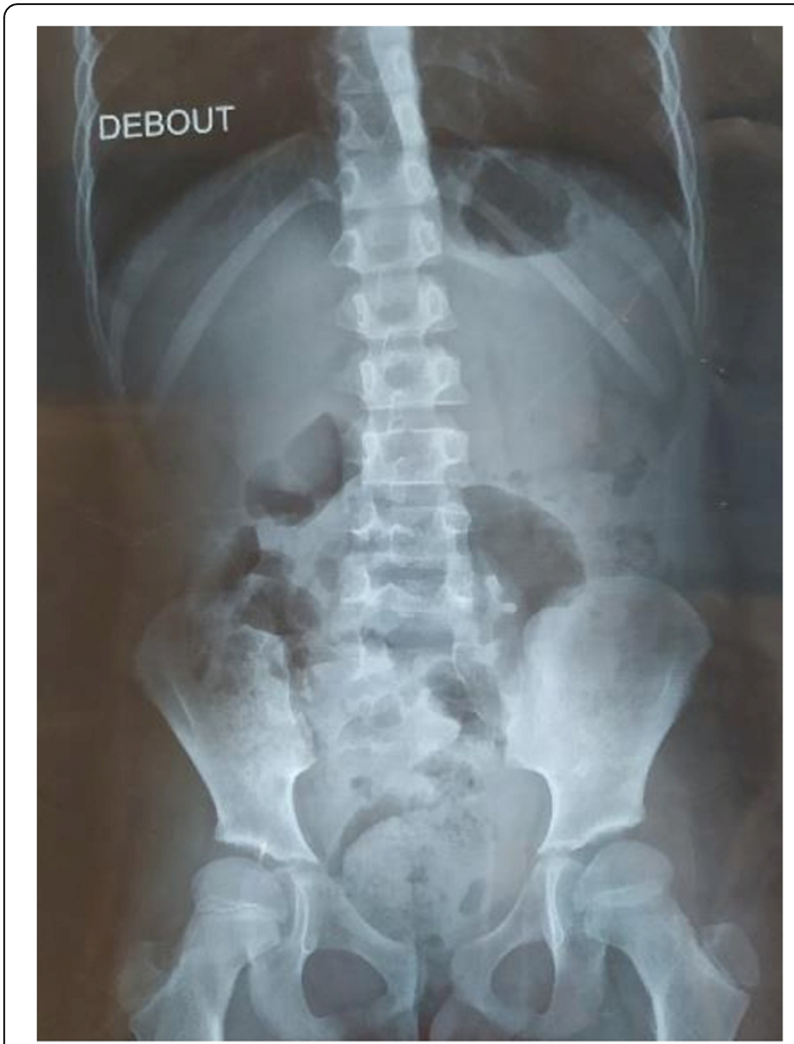

Fig. 1 Abdominal X-ray showing no specific gas pattern

transverse section, images showed a mass composed of multiple concentric circles (triple circle mass) (Fig. 2).

The patient underwent emergency exploratory laparotomy, which revealed a long intussuscepted ileal tract (Fig. 3). Manual reduction was performed and a compound ileo-ileo-ileal intussusception was found. The lead point of the intussusception was a $3-\mathrm{cm}$ hemispherical mass located $100 \mathrm{~cm}$ away from the ileocecal junction and originating from the antimesenteric border of the ileum (Fig. 4).

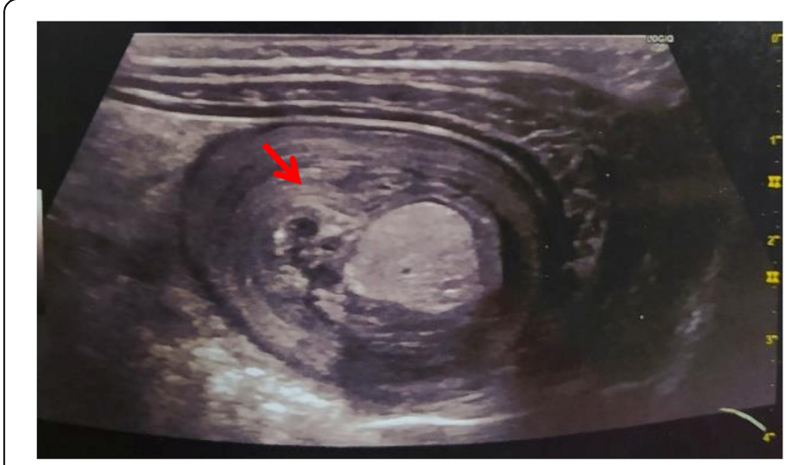

Fig. 2 Abdominal ultrasound revealed an intussusception with typical target sign (arrow)

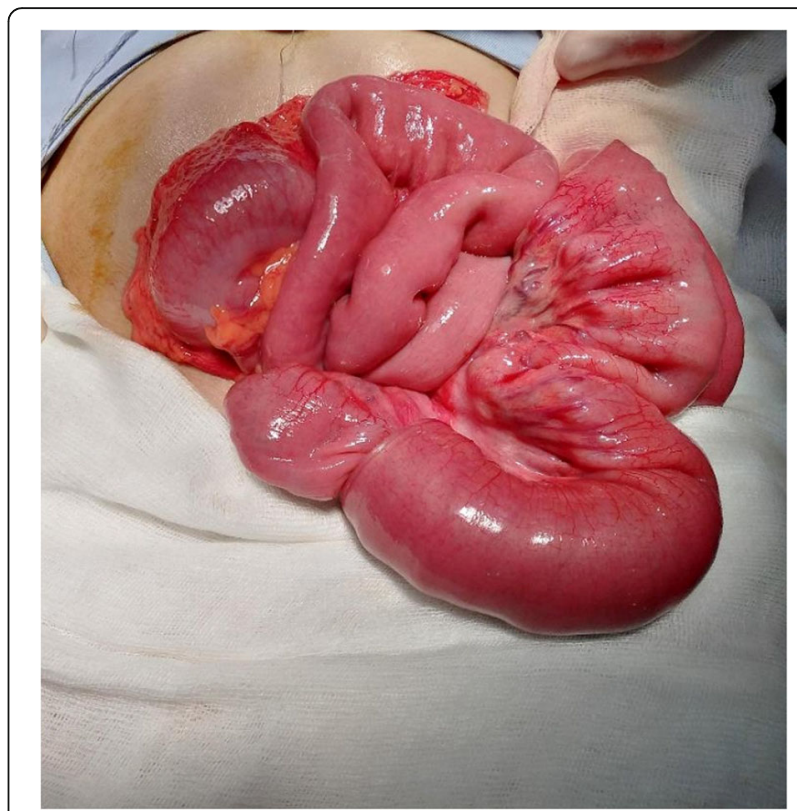

Fig. 3 Pre-operative view of compounded ileo-ileal intussusception

Resection and end-to-end anastomosis of the ileal segment containing the mass were performed with a $5-\mathrm{cm}$ safety margin on each side. Histopathological examination confirmed the diagnosis of a submucosal intestinal lipoma (Fig. 5). The postoperative course was uneventful and the patient was discharged after 1 week.

\section{Discussion}

Intussusception is a common pediatric surgical problem in infants and toddlers, with the highest incidence between 3 and 12 months. It is defined as the telescoping of one segment of the intestine into a distal segment. Most intussusceptions are idiopathic with a good prognosis. Secondary intussusceptions are caused by pathologic lead points (PLPs) (such as Meckel's diverticulum,

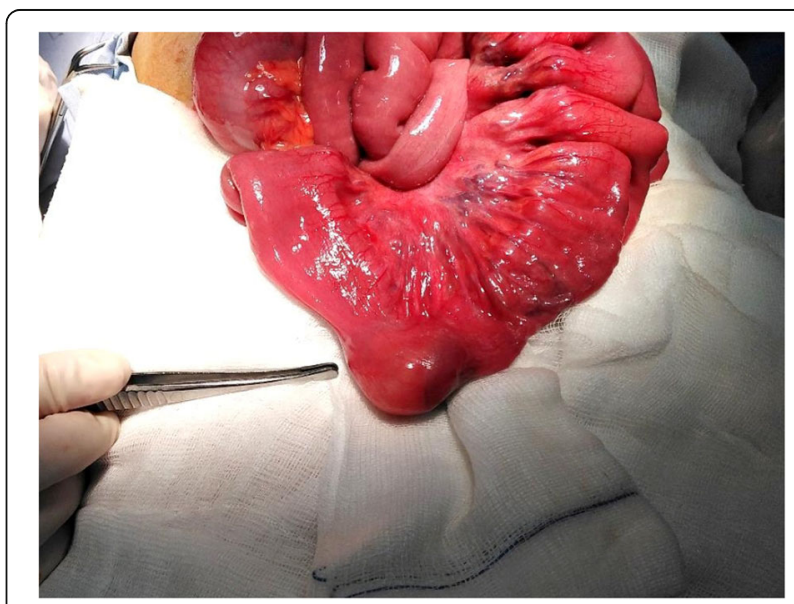

Fig. 4 Pre-operative view of submucosal lipoma 


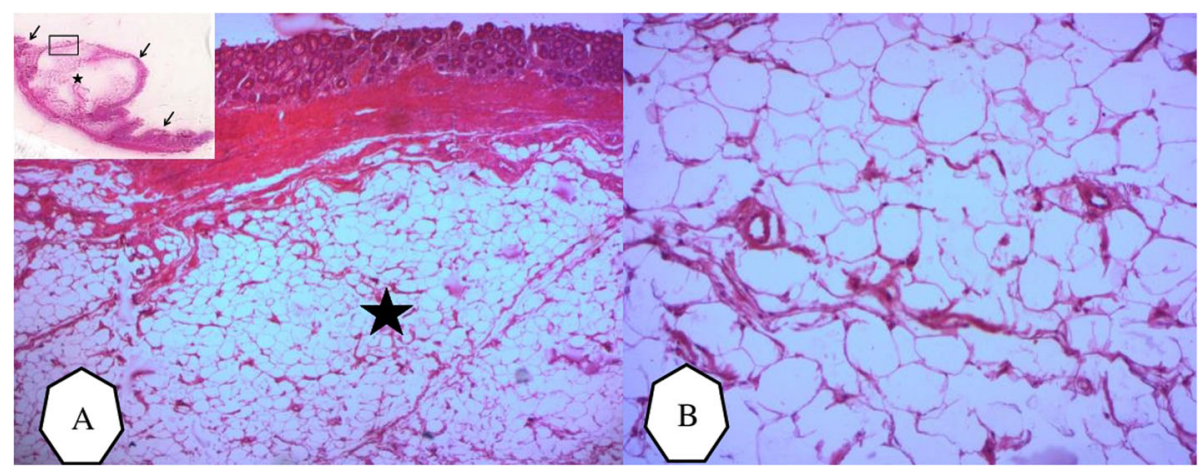

Fig. 5 Microscopic examination of small intestinal lipoma. A Low power examination showed lobules of fat separated by delicate fibrovascular trabeculae $\left(^{*}\right)$. (HEx25). B A high power examination showed mature fat cells with no malignant features. (HE x 100)

duplication, polyps, and tumors) and represent $2.2-15 \%$ of cases $[5,6]$. The incidence of intussusception secondary to PLPs is much higher in children $>2$ years old than in children $<2$ years of age [7]. They are relatively difficult to diagnose and confirm before surgery.

Lipomas of the GIT are benign intestinal tumors of mesenchymal origin. They are relatively rare and represent only $2.6 \%$ of nonmalignant tumors of the GIT [8]. Most lipomas are solitary, but they can be multiple and located anywhere in the GIT [9]. Lipomas are more frequent in the large intestine, mainly in the right colon and the cecum, and only $20-25 \%$ are found in the small intestine. There are three pathological types of intestinal lipomas: (i) intermuscular type; (ii) subserosal type; and (iii) submucosal type. The tumors arise from the submucosa in $90 \%$ of cases, while the remainder are usually subserosal [10]. Submucosal lipomas usually present as polypoid lesions, either sessile or pedunculated [11].

Lipomas of the small intestine are most likely to present during the fifth to seventh decade of life [12]. In older subjects, the incidence appears to be higher in females than in males [13].

These tumors are slow-growing with a silent clinical course and are usually found incidentally [14]. Symptoms such as abdominal pain, diarrhea, constipation, and bleeding tend to occur when the lesion is $>2 \mathrm{~cm}$ in size [15]. Lesions $<1 \mathrm{~cm}$ are rarely symptomatic, while $75 \%$ of those $>4 \mathrm{~cm}$ in size are more likely to cause symptoms. Small intestinal lipomas produce symptoms more often than colonic lipomas, irrespective of the size of the tumor [11].

Among children, intestinal intussusception due to lipoma as the PLP is rare. In fact, to our knowledge, this is only the seventh reported case of its kind. Table 1 summarizes the literature on pediatric small intestinal intussusception induced by a lipoma.

For pediatric small intestinal lipomas, median age at diagnosis is 8 years with a range from 4 to 14 years. All reported cases to date have been in males. Vomiting and recurrent abdominal pain have been reported to be the main symptoms. These symptoms are not specific and are shared with other gastrointestinal disorders. Thus, the correct diagnosis may be difficult to make [11].

Pre-operative diagnosis is important because the diagnosis can be difficult to make intra-operatively and a correct diagnosis can avoid unnecessary excessive resection. Simanovsky et al. [15] stated that surgery can be better planned when the exact location and extent of the intussusception are known from imaging [19].

Table 1 Reported pediatric cases of small intestinal lipoma in the English literature

\begin{tabular}{|c|c|c|c|c|c|c|}
\hline $\begin{array}{l}\text { Case/ } \\
\text { year }\end{array}$ & $\begin{array}{l}\text { Age } \\
\text { (years) }\end{array}$ & Sex & Diagnostic modality & $\begin{array}{l}\text { Pre-operative } \\
\text { imaging }\end{array}$ & Tumor location/intussusception type & Reference \\
\hline $1(1991)$ & 12 & Male & $\begin{array}{l}\text { Vomiting + epigastric pain mimicking acute } \\
\text { pancreatitis }\end{array}$ & $U S+C T+E R C P$ & $\begin{array}{l}\text { Duodenal lipoma/duodenal-jejunal } \\
\text { intussusception }\end{array}$ & [15] \\
\hline $2(1997)$ & 6 & Male & $\begin{array}{l}\text { Recurrent abdominal pain with vomiting and } \\
\text { weight loss }\end{array}$ & $\mathrm{CT}$ & $\begin{array}{l}\text { Duodenal lipoma/duodenal-jejunal } \\
\text { intussusception }\end{array}$ & [16] \\
\hline $3(2008)$ & 14 & Male & Recurrent abdominal pain and vomiting & CT & Ileal lipoma/ileo-colic intussusception & [1] \\
\hline $4(2013)$ & 7 & Male & Abdominal pain & $U S+C T$ & Ileal lipoma/ileo-ileal intussusception & [4] \\
\hline $5(2014)$ & 5 & Male & Abdominal pain & $U S+C T$ & Ileal lipoma/ileo-ileal intussusception & [17] \\
\hline $6(2018)$ & 4 & Male & Abdominal pain and vomiting & $U S+C T$ & Ileal lipoma/ileo-ileal intussusception & [18] \\
\hline 7 (2019) & 8 & Female & Recurrent abdominal pain and vomiting & US & Ileal lipoma/ileo-ileal intussusception & $\begin{array}{l}\text { Present } \\
\text { case }\end{array}$ \\
\hline
\end{tabular}


Pre-operative auxiliary examinations such as ultrasound and computed tomography (CT) scans are very helpful imaging modalities for the diagnosis of intussusception and for determining the nature of the intraluminal lesion [20]. Abdominal ultrasound will reveal a rounded echogenic mass typically described as the pseudokidney sign [21]. This technique is generally available in an emergency setting. In the hands of skilled and experienced sonographers, it has similar sensitivity and specificity to CT scans, allowing a correct diagnosis before surgery.

On CT scans, lipomas appear as well-circumscribed, round, homogeneous masses with fat attenuation numbers ( -40 to -120 Hounsfield units) within the lumen of the intussusceptions $[2,22]$. CT scans were not performed in our patient because of sufficient diagnostic data for a secondary intussusception was obtained by radiography and ultrasound, and because of the urgent condition of the patient.

The treatment of lipomas depends on their symptoms. Surgical resection is usually the treatment of choice for symptomatic gastrointestinal lipomas [16]. Partial small bowel resection can either be done by laparotomy or laparoscopy. Oncological principles should be maintained during resection unless pre-operative imaging shows a benign etiology [23]. The correct diagnosis of a symptomatic, submucosal lipoma is an indication for local excision and eliminates unnecessary extensive resection. In our patient, resection with a 5-cm safety margin on each side was performed because we did not exclude malignancy.

As for the rarity of these tumors, there is a view that this may be due to the lack of reporting of cases or to false diagnoses. In most cases, the histological diagnosis is made only after excision of the tumor. Therefore, pathological examination of all excised tissues may increase the detection of this clinical entity.

Treatment is usually definitive, because the lesions do not often recur. No malignant transformation of lipomas has been reported in the literature and after resection, no recurrence is expected $[16,24]$.

\section{Conclusions}

Small intestinal submucosal lipoma should be considered in case of intussusception in pediatric patients. Surgical resection seems sufficient in case of symptomatic intestinal lipoma with low morbidity.

\footnotetext{
Abbreviations

CT: Computed tomography; GIT: Gastrointestinal tract; PLP: Pathologic lead point
}

Acknowledgements

None.

\section{Authors' contributions}

TC conception, design of the work, literature review, manuscript writing, and editing. MBD operated the patient, manuscript writing, and literature review. RM concept design and manuscript review. All authors have read and approved the final manuscript.

\section{Funding}

None.

Availability of data and materials

None.

\section{Declarations}

Ethics approval and consent to participate

None.

Consent for publication

The parents of the patient have consented to use of clinical photographs for publication and research process.

Competing interests

All authors declare that they have no competing interests.

\section{Author details}

${ }^{1}$ Department of Pediatric Surgery, Hedi Chaker Hospital, 3029 Sfax, Tunisia. ${ }^{2}$ University of Medicine of Sfax, University of Sfax, Sfax, Tunisia. ${ }^{3}$ Department of Pathology, Habib Bourguiba Hospital, 3029 Sfax, Tunisia.

Received: 22 January 2021 Accepted: 24 June 2021

Published online: 02 August 2021

\section{References}

1. Draus JM, Shelgikar CS, Buchino JJ, Bond SJ. Lipoma as a pathological lead point in a child with ileocolic intussusception. J Pediatr Gastroenterol Nutr. 2008;47(3):372-4. https://doi.org/10.1097/MPG.0b013e318076b489.

2. Baron Y, Priesack W, Sötje G, Brix F, Scheunemann C. Hemorrhagic jejunal lipoma with intermittent intussusception. Eur J Radiol. 1996;22(2):123-5. https://doi.org/10.1016/0720-048X(96)00753-X.

3. Triantopoulou C, Vassilaki A, Filippou D, Velonakis S, Dervenis C, Koulentianos E. Adult ileocolic intussusception secondary to a submucosal cecal lipoma. Abdom Imaging. 2004;29:426-8.

4. Asaumi $Y$, Miyanaga T, Ishiyama $Y$, Hattori M, Hashizume $Y$. Pediatric ileoileal intussusception with a lipoma lead point: a case report. Gastroenterol Rep (Oxf). 2014;2(1):70-2. https://doi.org/10.1093/gastro/got032.

5. Wong CWY, Chan IHY, Chung PHY, Lan LCL, Lam WWM, Wong KKY, et al. Childhood intussusception: 17-year experience at a tertiary referral centre in Hong Kong. Hong Kong Med J. 2015;21(6):518-23. https://doi.org/10.12809/ hkmj144456.

6. Hsu W-L, Lee H-C, Yeung C-Y, Chan W-T, Jiang C-B, Sheu J-C, et al. Recurrent intussusception: when should surgical intervention be performed? Pediatr Neonatol. 2012;53(5):300-3. https://doi.org/10.1016/j. pedneo.2012.07.004

7. Zhao L, Feng S, Wu P, Lai X-H, Lv C, Chen G. Clinical characteristics and surgical outcome in children with intussusceptions secondary to pathologic lead points: retrospective study in a single institution. Pediatr Surg Int. 2019; 35(7):807-11. https://doi.org/10.1007/s00383-019-04471-8.

8. Ackerman NB, Chughtai SQ. Symptomatic lipomas of the gastrointestinal tract. Surg Gynecol Obstet. 1975:141:565-8.

9. Deeths TM, Madden PN, Dodds WJ. Multiple lipomas of the stomach and duodenum. Am J Dig Dis. 1975;20(8):771-4. https://doi.org/10.1007/BF01 070835

10. Charalambous $G$, Katergiannakis $\vee$, Manouras A. Jejunojejunal lipoma causing intussusception. Case Rep Gastroenterol. 2012;6(3):684-8. https:// doi.org/10.1159/000345379.

11. Janevska V, Spasevska L, Dukova B, Janevski V. Intestinal submucosal lipomas. Mac J Med Sci. 2012;5(1):49-54. https://doi.org/10.3889/MJMS.18575773.2012.0199.

12. Fang S-H, Dong D-J, Chen F-H, Jin M, Zhong B-S. Small intestinal lipomas: Diagnostic value of multi-slice CT enterography. World J Gastroenterol. 2010;16(21):2677-81. https://doi.org/10.3748/wjg.v16.i21.2677. 
13. Manouras A, Lagoudianakis EE, Dardamanis D, Tsekouras DK, Markogiannakis $\mathrm{H}$, Genetzakis M, et al. Lipoma induced jejunojejunal intussusception. World J Gastroenterol. 2007;13(26):3641-4. https://doi.org/10.3748/wjg.v13.i26.3641.

14. Turi S, Röckelein G, Dobroschke J, Wiedmann KH. Lipoma of the small bowel. Z Gastroenterol. 2004;42(2):147-51. https://doi.org/10.1055/s-2004812837.

15. McGrath FP, Moote DJ, Langer JC, Orr W, Somers S. Duodenojejunal intussusception secondary to a duodenal lipoma presenting in a young boy. Pediatr Radiol. 1991;21(8):590-1. https://doi.org/10.1007/BF02012606.

16. Case records of the Massachusetts General Hospital. Weekly clinicopathological exercises. Case 24-1997. A six-year-old boy with bouts of abdominal pain, vomiting, and a left-sided abdominal mass. N Engl J Med. 1997;337:329-36.

17. Destro F, Cantone N, Maffi M, Gargano T, Lima M. An interesting case of double compound intussusception without intestinal occlusion in a 5-yearold boy. Eur J Pediatr Surg Rep. 2014;2(01):20-2. https://doi.org/10.1055/s0033-1361925.

18. Abdelmohsen SM, Osman MA, Hussien MT. An ileo-ileal intussusception secondary to polypoid lipoma in a child, a case report and review of the literature. Int J Surg Case Rep. 2019;57:88-90. https://doi.org/10.1016/j.ijscr.2 019.03.003.

19. Simanovsky N, Hiller N, Koplewitz BZ, Eliahou R, Udassin R. Is non-operative intussusception reduction effective in older children? Ten-year experience in a university affiliated medical center. Pediatr Surg Int. 2007;23(3):261-4. https://doi.org/10.1007/s00383-006-1838-x.

20. Tan HL, Koh YX, Taufik M, Lye WK, Goh BKP, Ong HS. A clinical scoring system to predict the clinical sequelae of computed tomography diagnosed intussusception. World J Surg. 2018;42(3):682-7. https://doi.org/1 0.1007/s00268-017-4196-z.

21. Vagholkar K, Chavan R, Mahadik A, Maurya I. Lipoma of the small intestine: a cause for intussusception in adults. Case Rep Surg. 2015:e856030 [Open Access] Available at https://www.hindawi.com/journals/cris/2015/856030/ (accessed 17/11/20)

22. Chekan EG, Westcott C, Low VHS, Ludwig KA. Small bowel intussusception and laparoscopy. Surg Laparosc Endosc. 1998;8(4):324-6. https://doi.org/10.1 097/00019509-199808000-00019.

23. Oyen TL, Wolthuis AM, Tollens T, Aelvoet C, Vanrijkel JP. Ileo-ileal intussusception secondary to a lipoma: a literature review. Acta Chir Belg. 2007;107(1):60-3. https://doi.org/10.1080/00015458.2007.11680013.

24. Eisen LK, Cunningham JD, Aufses AH. Intussusception in adults: institutional review. J Am Coll Surg. 1999;188(4):390-5. https://doi.org/10.1016/S1072-751 5(98)00331-7.

\section{Publisher's Note}

Springer Nature remains neutral with regard to jurisdictional claims in published maps and institutional affiliations.

\section{Submit your manuscript to a SpringerOpen ${ }^{\circ}$ journal and benefit from:}

- Convenient online submission

- Rigorous peer review

- Open access: articles freely available online

- High visibility within the field

- Retaining the copyright to your article

Submit your next manuscript at $\boldsymbol{\nabla}$ springeropen.com 